\title{
KOMPETENSI KESUSASTRAAN GURU BAHASA DAN SASTRA INDONESIA DI WILAYAH TANGERANG SELATAN
}

\author{
Ahmad Bahtiar \\ UIN Syarif Hidayatullah Jakarta \\ ahmad.bahtiar@uinjkt.ac.id
}

\begin{abstract}
Abstrak
Kompetensi kesusastraan kini tengah dikritisi oleh berbagai pihak yang memperhatikan lemahnya pembelajaran sastra di sekolah, khususnya sekolah menengah. Untuk itu penelitian dengan sasaran atau responden guru bahasa dan sastra Indonesia sekolah menengah di wilayah Kotamadya Tangerang Selatan dilaksanakan. Tulisan dengan metode deksriptif-analisis ini mendeskripsikan kompetensi yang mencakup memahami pengetahuan sastra, keberminatan dan pengalaman sastra serta keikutsertaan dalam perkembangan sastra. Data yang diperoleh dianalisis serta dikomparasikan dengan standar kompetensi kesusastraan yang ideal. Sehubungan itu intrumen yang digunakan untuk tulisan ini yaitu angket atau kuesioner. Hasil penelitian menunjukkan bahwa guru bahasa dan sastra Indonesia di wilayah Kotamadya Selatan berdasarkan kompetensi kesusastraan masih jauh dari kriteria guru bahasa dan sastra Indonesia ideal. Untuk itu perlunya upaya meningkatkan kompetensi guru bahasa dan sastra Indonesia khususnya berkenaan dengan kesastraan.
\end{abstract}

Kata Kunci : kompetensi, kesusastraan, guru bahasa Indonesia, Tangerang Selatan

\begin{abstract}
Literary competence is now criticized by the experts who pay attention on the weakness of the literature teaching-learning at schools, especially secondary schools. Therefore, this research focusing on the Indonesian language and literature teacher in secondary schools in the Municipality of Tangerang Selatan was conducted. Ths is a descriptive analysis research which explains the competencies including understanding literary knowledge, students' literary interest and experience, and participation in developing literary activities. The data of this researchs were analyzed and compared to the ideal literary competence standards. The instrument of this research was questionnaire. The results of this research show that based on the literary competence, the Indonesian language and literature teachers in the municipality of Tangerang Selatan do not meet required standards as an ideal teacher. Therefore, it is proposed that some efforts to improve the competency of Indonesian language and literature teachers in the literature understanding and implementing on the teaching-learning process are necessary.
\end{abstract}

Keywords: competence, literature, Indonesian teacher, Tangerang Selatan

\section{A. Pendahuluan}

Pembelajaran bahasa Indonesia merupakan pembelajaran yang senantiasa menjadi sorotan masyarakat karena memiliki keistimewaan di antara pembelajaran yang ada di sekolah. Pertama, pembelajaran bahasa Indonesia merupakan salah satu 
pembelajaran yang di-UN-kan. Kedua, terkait dengan nama "bahasa Indonesia" yang memiliki berbagai predikat, yakni sebagai bahasa persatuan, bahasa negara, dan bahasa nasional sehingga pembelajaran bahasa Indonesia menjadi penting untuk dipelajari. Bahkan, saat ini kedudukan pembelajaran bahasa Indonesia menjadi indikator untuk "perekat bangsa".

Dalam konteks kurikulum 2013, Nuh (dalam Mahsum, 2013: 1) menjelaskan bahasa Indonesia menjadi lebih istimewa karena ditempatkan sebagai penghela ilmu pengetahuan. Keistimewaan tersebut karena bahasa Indonesia dalam kurikulum 2013 diorientasikan pada pembelajaran berbasis teks, terlihat pada rumusan kompetensi dasar substansi bahasa Indonesia dari pendidikan dasar sampai pendidikan tinggi.

Pemerintah melalui Undang-Undang Nomor 24 tahun 2009 tentang Bendera, Bahasa, dan Lagu Kebangsaan, serta Lambang Negara pada pasal 29 ayat (1) menyatakan "Bahasa Indonesia wajib digunakan sebagai bahasa pengantar dalam pendidikan nasional". Pernyataan tersebut mengukuhkan dan menguatkan posisi bahasa Indonesia dalam dunia pendidikan. Keberhasilan pembelajaran bahasa Indonesia sangat menentukan akan kewibawaan dan kehormatan bahasa Indonesia. Oleh sebab itu, guru bahasa Indonesia perlu memiliki kompetensi sebagaimana yang diatur dalam Peraturan Pemerintah Nomor 19 Tahun 2005 tentang Standar Nasional Pendidikan.

Kompetensi dalam dunia pendidikan menjadi syarat mutlak profesionalisme. Hal itu ditunjukkan melalui pemenuhan kualifikasi yang sesuai dengan standar nasional pendidikan. Kualifikasi ini meliputi sikap, pengetahuan, dan keterampilan yang diwujudkan melalui kompetensi pedagogik, kompetensi profesional, kompetensi kepribadian, dan kompetensi sosial. Guru yang berkualifikasi berarti mampu menguasai materi pembelajaran, memahami psikologi perkembangan peserta didik, dan menguasai strategi pembelajaran beserta media yang diperlukan.

Kompetensi yang berkaitan langsung dalam pembelajaran di kelas adalah kompetensi pedagogik dan profesional. Kedua kompetensi itu pun akan menampakkan kualifikasi akademik seorang pengajar bahasa dan sastra. Dalam lampiran Permendiknas No. 16 Tahun 2007 tentang Standar Kualifikasi Akademik dan Kompetensi Guru, dideskripsikan kompetensi inti guru dari jenjang TK/PAUD, SD/MI, SMP/MTs, SMA/MA, dan SMK/MAK. Akan tetapi, kompetensi kesusastraan tidak dimunculkan secara eksplisit. 


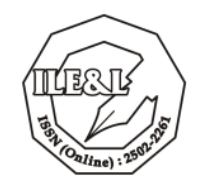

Journal Indonesian Language Education and Literature Vol. 2, No. 2, 2017

http://www.syekhnurjati.ac.id/jurnal/index.php/jeill/

Kompetensi kesusastraan yang menjadi salah satu pilar dalam kurikulum mata pelajaran bahasa dan sastra Indonesia, kini tengah dikritik oleh berbagai pihak yang memperhatikan lemahnya pembelajaran sastra di sekolah, khususnya sekolah menengah. Kurangnya pembelajaran sastra di sekolah menyebabkan kurangnya minat terhadap karya sastra apalagi membaca karya sastra. Tak aneh budaya membaca di kalangan siswa sekolah menengah di Indonesia sangat rendah dibandingkan siswa lainnya di luar negeri. Hal ini dibuktikan dengan dengan jumlah buku yang dibacanya. Siswa di luar negeri setiap tahun bisa membaca enam sampai tujuh buku. Bahkan di beberapa negara mencapai puluhan buku sedangkan siswa sekolah menengah di Indonesia, nol buku. Artinya tidak ada satupun buku yang dibaca, apalagi yang dibahas bersama-sama sampai tuntas. Gejala tersebut oleh penyair Taufiq Ismail dengan istilah "rabun membaca dan lumpuh menulis".

Kritik ini telah cukup lama diajukan, sejak dimulainya program Sastra Masuk Sekolah yang diinisiasi oleh Pusat Bahasa (kini Badan Bahasa) pada tahun 2000. Program tersebut kemudian dilanjutkan dengan diklat Membaca, Menulis, dan Apresiasi Sastra (MMAS) yang melibatkan guru-guru sekolah menengah Se-Indonesia. Berbagai kegiatan tersebut dibuat untuk menjembatani kesenjangan antara kompetensi guru bahasa Indonesia dalam mengajarkan sastra dengan kemampuan siswa dalam mengapresiasi sastra. Sejumlah publikasi tentang program "Sastra Masuk Sekolah", "Siswa Bertanya Sastrawan Menjawab", dan diklat "Membaca, Menulis, dan Apresisasi Sastra” (MMAS) menunjukkan hasil evaluasi kegiatan tersebut, bahwa 1) rendahnya apresiasi sastra siswa ekuivalen rendahnya minat guru bahasa terhadap materi sastra, 2) kurangnya pustaka bahan bacaan sastra yang memungkinkan siswa dan guru membaca bersama, 3) rendahnya kreativitas guru dalam strategi pembelajaran sastra untuk siswa sekolah menengah.

Dengan demikian, kompetensi kesusastraan para guru juga perlu dipertimbangkan dari segi paradigma pendekatan mereka saat mengajarkan sastra kepada siswa didiknya. Upaya pemetaan kompetensi ini akan dikhususkan pada kompetensi kesusastraan mengingat permasalahan krusial dalam pembelajaran sastra di sekolah yang kini tengah dihadapi di negeri ini. Berdasarkan paparan tersebut, akan dideskripsikan "Kompetensi Kesusastraan Guru Bahasa dan Sastra Indonesia (Studi Kasus di Wilayah Kotamadya 
Tangerang Selatan)" berdasarkan survei dan angket terhadap guru-guru di Sekolah Menengah di Tangerang Selatan.

Kompetensi profesional yang harus dimiliki seorang guru bahasa dan sastra Indonesia diantaranya memahami teori dan genre sastra Indonesia dan mampu mengapresiasi karya sastra Indonesia secara reseptif dan produktif (Permendiknas No. 16). Untuk mendukung kompetensi profesional tersebut perlunya guru memiliki kompentensi lainnya yang berhubungan dengan kesusastraan sehingga pengajaran sastra di sekolah menimbulkan minat siswa belajar sastra. Kompetensi kesusastran yang harus dimiliki untuk menjadi guru sastra ideal mencakup memahami teori sastra sastra dan sejarah sastra, berminat pada sastra, pengalaman baca, dan mengikuti perkembangan sastra (Rozak, 2012). Selain itu, perlu dimasukkan pengalaman bersastra sebagai bagian persyaratan tersebut. Pemahaman teori dan sejarah sebagai bagian ilmu sastra dilengkapi dengan kajian atau pendekatan sastra.

\section{B. Metode Penelitian}

Tulisan ini menggunakan metode deksriptif-analisis untuk mendeskripsikan kompetensi yang mencakup memahami pengetahuan sastra, keberminatan, dan pengalaman sastra serta keikutsertaan dalam perkembangan sastra. Data yang diperoleh dideskripsikan dan dianalisis serta dikomparasikan dengan standar kompetensi kesusastraan yang ideal. Instrumen ini menggunakan beberapa pertanyaan atau pernyataan tertulis yang telah disedi akan alternatif jawabannya. Angket yang diberikan kepada responden berkenaan kompetensi kesusastraan guru bahasa dan sastra di wilayah Kotamadya Tangerang Selatan. Responden adalah guru bahasa Indonesia pada sekolah menengah, baik SMP/MTs, SMA/MA, dan SMK baik negeri dan swasta di Wilayah Tangerang Selatan.

Sasaran dalam penelitian ini adalah guru bahasa dan Sastra Indonesia di wilayah Kotamadya Tangerang Selatan yang tersebar di 157 sekolah. Jumlah guru bahasa dan sastra Indonesia yang dimiliki setiap sekolah bervariasi tergantung kebutuhan dan kemampuan sekolah. Untuk mengambil deskripsi dari kompetensi kesusastraan guru tersebut, penulis mengambil $20 \%$ dari keseluruhan, yaitu 31 sekolah dari keseluruhan sekolah menengah di Kotamadya Tangerang Selatan. Adapun guru yang menjadi respondennya sejumlah 40 orang yang berasal dari semua tingkatan satuan pendidikan 
menengah, SMP/MTs dan SMA/MA/SMK, baik negeri maupun swasta. Responden dipilih dari semua tingkatan satuan pendidikan menengah agar sebaran responden dalam penelitian ini proporsional karena adanya keterwakilan setiap satuannya.

Angket yang digunakan sebagai alat pengumpul data setelah disebar kepada responden kemudian dianalisis untuk memperoleh gambaran kompetensi kesusastraan guru bahasa dan sastra Indonesia di wilayah Kotamadya Tangerang Selatan. Setelah angket terkumpul kemudian dideskripsikan secara persentase dari setiap jawaban setiap responden sesuai tujuan penelitian ini.

\section{Hasil dan Pembahasan}

Kompetensi tersebut dirinci dalam indikator yang mencakup Ilmu Sastra terdiri atas, 1) memahami fungsi dan manfaat sastra; 2) memahami klasifikasi sastra; 3) memahami unsur puisi; 4) memahami unsur prosa; 5) memahami unsur drama; 6) memahami periodisasi atau angkatan sastra; 7) memahami aliran-aliran sastra; 8) memahami peristiwa-peristiwa sastra; dan 9) memahami metode kajian sastra atau pendekatan sastra. Sedangkan kompetensi peminatan pada satra mencakup: 1) membaca buku karya sastra; 2) membaca karya sastra koran atau majalah umum; 3) membaca buku-buku ilmu sastra; 4) membaca majalah atau jurnal sastra; 5) menyediakan waktu khusus untuk sastra; 6) menyediakan dana untuk sastra; 7) mendatangi perpustakaan; dan 8) menyaksikan pementasan sastra.

Adapun yang berkaitan dengan pengalaman sastra meliputi, 1) menyelenggarakan kegiatan sastra; 2) mengikuti pementasan; 3) membaca puisi di depan umum; 4) membaca prosa di depan umum; 5) menulis puisi; 6) menulis cerpen atau novel;7) menulis naskah drama; 8) menulis esai sastra; 9) mengikuti lomba sastra; dan 10) menjadi juri lomba sastra. Kompetensi terakhir, yaitu mengikuti perkembangan sastra yang terdiri atas 1) mengenal sastrawan-sastrawan kontemporer; 2) mengenal kritikus sasta Indonesia kontemporer; 3) membaca ulasan-ulasan sastra; 4) mengikuti diskusi atau seminar sastra; 5) mengikuti penghargaan untuk sastrawan; 6) mengikuti pelatihan sastra; 7) mengikuti komunitas atau grup sastra; dan 8) melakukan penelitian sastra.

\section{Karakteristik Responden}

Guru bahasa dan sastra Indonesia di wilayah Kotamadya Tangerang Selatan yang menjadi responden dalam penelitian ini didominasi perempuan $76 \%$ sedangkan 
responden laki-laki 24\%. Pendidikan guru-guru tersebut umumnya sarjana $86 \%$ sedangkan yang sudah atau magister $7 \%$. Sisanya yang masih menempuh pendidikan sarjana atau masih kuliah 7\%. Lamanya mengajar atau pengalaman sebagai guru hampir sebagian besar responden kurang 10 tahun (41\%). Responden yang memiliki pengalaman mengajar antara 10-20 tahun (36\%). Sisanya responden yang sudah mengajar lebih dari 20 tahun $(8 \%)$.

Berdasarkan angket yang disebar kepada responden diperoleh gambaran kesusastraan guru bahasa Indonesia di wilayah Kotamadya Tangerang Selatan dengan uraian sebagai berikut.

1) Memahami Ilmu Sastra

Kondisi guru bahasa dan sastra Indonesia di wilayah Kotamadya Tangerang berdasarkan pemahaman ilmu sastra mencakup pemahaman fungsi dan manfaat sastra, klasifikasi sastra, unsur pembangun sastra (puisi, prosa, dan drama), periodisasi atau angkatan sastra, aliran sastra, peristiwa sastra metode dan pendekatan kajian sastra.

2) Memahami Fungsi dan Manfaat Sastra

Fungsi dan manfaat sastra dipahami oleh (46\%) responden. Sedangkan sebagian besar responden (51\%) merasa cukup paham perasaan menyenangkan (dulce) dan bermanfaat (utile) dalam bersastra. Sisanya (3\%) responden kurang memahami tentang manfaat sastra tersebut. Kondisi ini kurang baik karena guru bahasa dan sastra Indonesia harus paham benar tentang fungsi dan manfaat sastra terutama untuk siswanya. Sastra akan memperkaya pengalaman siswa dan menjadikannya lebih tanggap terhadap alam sekitar dan lingkungannya. Siswa sekolah menengah yang sedang mengalami pembentukan pribadi dan budaya dituntut untuk dapat menyelami isi dari karya sastra. Karena dengan demikian ketika di masyarakat, mereka selain dapat memahami dirinya dan lingkungan sekitar, tetapi juga dapat mengembangkan dirinya di tengah masyarakat.

3) Memahami Klasifikasi Sastra

Sastra diklasifikan atau digolongkan berdasarkan beberapa aspek. Salah satunya berdasarkan mutu atau kualitasnya. Berdasarkan klasifikasi tersebut dikenal sastra serius dan sastra populer atau yang biasa disebut roman picisan. Penelitian ini menggambarkan bahwa responden yang cukup memahami klasifikasi sastra 
sebanyak (45\%). Pilihan tersebut lebih banyak daripada yang mengusai mengetahui sebanyak $(42,5 \%)$ responden sedangkan yang memilih kurang mengetahui pembagian sastra ini sastra sebanyak $(12,5 \%)$ responden.

4) Memahami Unsur Puisi

Responden menguasai unsur puisi dengan tingkat yang beragam. Paling banyak pada tingkat mengusai sejumlah $(73 \%)$ responden. Beberapa responden cukup mengetahui (21\%) tentang bait, larik, rima, irama, tipografi, kata konkret, gaya bahasa serta unsur pembangun puisi lainnya. Responden yang memilih kurang memahami unsur karya sastra paling tua dan paling banyak ditulis ini sebanyak (6\%) responden.

5) Memahami Unsur-unsur Prosa

Prosa (novel dan cerpen) termasuk cerita rekaan yang cukup populer. Banyak menulis buku tentang teori-teori tersebut berdasarkan pandangannya. Responden pada umumnya mengusai (68\%) tentang unsur prosa yang meliputi tema, amanat, sudut pandang, alur, latar atau setting, gaya bahasa, dan tokoh serta penokohan. Beberapa responden hanya cukup mengusai (26\%) dan sisanya hanya (6\%) responden kurang menguasai teori tentang unsur prosa ini.

6) Memahami Unsur-unsur Drama

Dalam hal pengusaan teori, unsur drama yang meliputi tema, amanat, latar, penokohan, adegan, babak, dialog, dan lainnya, responden yang menjawab lebih banyak mengusai sebesar (60\%) responden, yang memilih cukup (35\%) responden sedangkan yang kurang mengusai terdapat (5\%) responden. Kondisi tersebut sangat baik karena siswa akan mendapat pengajaran drama yang baik. Melalui drama siswa dapat mempelajari peran-peran yang dimainkan beragam-ragam contohnya: sedih, marah, dan senang. Selain itu, siswa juga dapat merasakan hidup secara bebas, bebas dalam arti bisa mengekspresikan imajinasi yang terpendam atau tidak bisa dikeluarkan di dalam kehidupan sehari-hari.

7) Memahami Periodisasi Sastra

Pengetahuan sejarah sastra perlu dimiliki seorang guru bahasa dan sastra Indonesia. Salah satu hal penting dalam sejarah sastra ialah periodisasi atau angkatan dalam perkembangan sastra di Indonesia. Pengetahuan tentang hal itu belum banyak diketahui oleh para responden. Responden umumnya merasa cukup berkenaan 
tentang periodisasi atau angkatan dalam sastra (50\%). Responden yang menguasai pembabakan dalam sejarah sastra itu (38\%) sedangkan sisanya (40\%) responden. Adapun yang tidak mengusai terdapat $(2 \%)$ responden. Pengetahuan tersebut diperlukan untuk mengetahui gambaran perkembangan para pengarang selain untuk memudahkan dalam pemilihan kriteria karya sastra yang akan di baca. Karena hanya karya-karya penting dan mewakili corak dalam angkatannya yang dicatat dalam sejarah sastra Indonesia.

8) Memahami Aliran-aliran Sastra

Berbagai aliran sastra tersebut tidak banyak dikuasai oleh responden. Sebanyak (60\%) responden merasa cukup memahami tentang aliran sastra. Responden yang merasa mengusai aliran sastra hanya $(22,5 \%)$ sedangkan sisanya sebanyak $(15 \%)$ responden yang kurang memahami. Responden yang tidak mengetahui tentang aliran sastra tersebut sebanyak $(2,5 \%)$ responden. Penguasaan guru bahasa dan sastra Indonesia terhadap hal di atas sangat penting. Aliran-aliran dalam sastra selain mewakili setiap perkembangan sejarah sastra juga menjadi identitas lain para pengarang.

9) Memahami Peristiwa-peristiwa Sastra

Berbagai peristiwa yang terjadi dalam perkembangan sastra seperti lahirnya Balai Pustaka, terbitnya Majalah Pujangga Baru, Polemik Kebudayaan, Pengadilan Puisi, Heboh Sastra, Sastra Populer, Sastrawangi, Sastra Cyber, dan peristiwa lainnya hanya dikusai (18\%) responden. Responden yang merasa cukup memahami berbagai peristiwa sastra sebesar (70\%). Responden yang kurang menguasai peristiwa-peristiwa sastra sebesar (10\%). Selebihnya tidak mengusai salah satu bagian dalam sejarah sastra tersebut sebesar (2\%).

10) Memahami Metode Kajian atau Pendekatan Sastra

Pengetahuan tentang metode hanya dikuasi $(27,5 \%)$ responden. Sebagian besar responden memilih cukup (52,5\%). Responden yang memilih kurang dalam memahami metode kajian sastra sebesar $(17,5 \%)$. Responden yang tidak menguasai metode dalam kajian sastra sebanyak $(2,5 \%)$. Kegiatan mengkaji atau menelaah sastra menguras pikiran dan perhatian selain harus memahami beberapa unsur pembangun sastra. Hal ini yang menyebabkan teori ini kurang mendapat perhatian di kalangan guru-guru. 
11) Berminat pada Sastra

Minat sastra seorang guru akan mengalir pada siswanya. Untuk itu guru bahasa dan sastra Indonesia yang profesional harus memiliki minat yang tinggi dalam sastra. Berikut uraian tentang gambaran responden tentang minat pada sastra berkenaan kebiasaan membaca buku sastra, majalah atau jurnal sastra, ketersediaan waktu serta dana untuk kegiatan bersastra, kunjungan ke perpustakaan dan ke tempat pementasan sastra.

12) Membaca Buku Sastra

Minat siswa terhadap sastra akan muncul jika guru memperlihatkan minatnya terhadap sastra. Minat guru terhadap sastra ditandai dengan kegiatan membaca karya sastra. Responden yang sering membaca karya sastra baik puisi, prosa, maupun drama sebanyak (32,5\%). Sebagian besar responden menjawab cukup dalam membaca buku karya sastra (62,5\%) sedangkan sisanya (5\%) responden kurang dalam membaca buku karya sastra. Gambaran itu sangat menyedihkan karena sebagaian besar responden hanya cukup dalam membaca buku karya sastra. Guru bahasa dan sastra Indonesia yang profesional dituntut sering membaca karya sastra dan membaca buku sastra sebanyak-sebanyaknya. Ia harus menjadi contoh dalam membaca sastra agar siswanya terbiasa dalam membaca sastra. Dengan membaca karya sastra, siswa akan memiliki pengalaman-pengalaman baru tanpa menempuh risiko yang dapat mengecewakan ataupun membebani dirinya.

13) Membaca Karya Sastra Koran atau Majalah Umum

Sebagian besar responden cukup sering $(62,5 \%)$ membaca karya sastra dalam koran atau majalah umum. Responden yang menjawab sering (47,5\%). Responden yang menjawab kurang membaca karya sastra dalam koran atau majalah umum $(7,5 \%)$ dan menjawab tidak pernah $(2,5 \%)$ responden.

14) Membaca Buku-buku Ilmu Sastra

Guru-guru bahasa dan sastra Indonesia dapat memanfaatkan buku-buku Ilmu sastra untuk menambah pengetahuan sastranya. Dengan keluasan pengetahuan sastranya, ia menambah kualitas pembelajar sastra di kelas sehingga pembelajaran membosankan dan tidak menarik siswa tidak akan terjadi. Ironisnya, hal itu tidak terlukiskan dalam penelitian ini karena lebih dari setengah (70\%) responden hanya cukup dalalm membaca buku-buku ilmu sastra yang mencakup teori, sejarah, dan 
kritik atau sastra. Sedangkan yang menjawab sering membaca buku-buku tersebut sebanyak (12,5\%). Sisanya kurang dalam membaca buku-buku ilmu sastra sebesar $(15,5 \%)$, dan tidak pernah sebesar $(2,5 \%)$ responden.

15) Membaca Majalah atau Jurnal Sastra

Pemanfaatan majalah atau jurnal sastra tersebut tidak terlihat pada responden penelitian ini. Umumnya responden hanya menjawab cukup membaca majalah atau jurnal sastra sebesar $(57,5 \%)$. Sedangkan yang menjawab sering membaca majalah atau jurnal sastra sebesar (5\%). Selebihnya kurang membaca majalah dan jurnal sastra sebanyak (35\%) responden dan tidak pernah (2,5\%) responden.

16) Menyediakan Waktu Khusus untuk Sastra

Gambaran guru sastra ideal belum tampak pada penelitian ini. Responden menyediakan waktu khusus untuk kegiatan sastra baik hanya berkisar pada jawaban cukup (50\%) responden. Sedangkan sisanya hanya (12,5\%) responden sering menyedikan waktu khusus. Responden yang menjawab kurang sebanyak (32,5\%), Selebihnya pernah menyediakan waktu khusus sebanyak (5\%) responden.

17) Menyediakan Dana untuk Sastra

Umumnya responden tidak menyediakan dana khusus untuk kegiatan bersastra. Dana untuk membeli buku atau majalah sastra,menyaksikan pementasan sastra, dan kegiatan bersastra lainnya. Responden yang sering menyediakan dana khusus untuk kegiatan meningkatkan kompetensi sastranya ini hanya (4\%). Sebagian besar responden hanya cukup menyediakan dana untuk membeli buku atau kegiatan sastra lainnya (40\%). Sedangkan yang kurang menyediakan terdapat (30\%) responden, selebihnya (20\%) responden tidak pernah menyediakan dana untuk bersastra.

18) Mendatangi Perpustakaan

Berbagai alasan menyebabkan sebagian responden tidak sering mendatangi perpustakaan. Mereka yang hanya cukup datang ke perpustakaan sebesar (52,5\%). Responden yang sering ke perpustakaan sebanyak (35\%) responden sedangkan yang kurang sering datang ke perpustakaan (10\%) responden. Sisanya sebanyak $(5 \%)$ responden menjawab tidak pernah mendatangi perpustakaan. 
19) Menyaksikan Pementasan Sastra

Gambaran guru bahasa dan sastra Indonesia ideal masih jauh dari responden dalam penelitian ini. Setengah responden (50\%) kurang menyaksikan pementasan sastra. Responden yang sekadar menjawab cukup menyaksikan pementasan sebesar (35\%) responden. Sedangkan sisanya (10\%) menjawab sering sebanyak (10\%) responden dan tidak pernah $(2,5 \%)$ responden yang hadir dalam pementasan sastra.

20) Pengalaman Sastra

Guru sastra dituntut dapat menyelenggarakan kegiatan sastra, ikut pementasan sastra, membaca karya sastra di depan umum, menulis karya dan esai sastra mengikuti lomba, dan pernah menjadi juri lomba sastra sebagai bagian dari pengalaman sastra.

21) Menyelenggarakan Kegiatan Sastra

Kegiatan sastra yang dapat dilakukan guru bahasa dan sastra Indonesia adalah membuat pertunjukan teater di sekolah. Pementasan tersebut dapat mengkolaborasikan berbagai keterampilan siswa dengan berbagai guru bidang studi lainnya. Aktivitas sastra ini juga dapat dijadikan sebagai ujian praktik berbagai mata pelajaran. Namun, aktivitas ini sangat kompleks dan melibatkan banyak orang. Oleh karena itu, sebagian responden (52,5\%) menjawab hanya cukup sedangkan yang sering menjawab ktivitas sastra ini sebanyak (17,5\%) responden. Sisanya kurang (30\%) responden, dan tidak pernah $(7,5 \%)$ responden dalam menyelenggarakan kegiatan sastra.

22) Mementaskan Sastra

Guru bahasa dan sastra Indonesia yang menguasai sastra tidak terlukiskan dalam penelitian ini. Responden sebanyak (47,5\%) umumnya kurang ikut serta dalam pementasan sastra. Sedangkan yang sering ikut pementasan sastrahanya $(2,5 \%)$ responden. Sisanya memilih cukup dalam keikutsertaan pementasan sastra sebesar (40\%) responden dan memilih tidak pernah sebanyak (7,5\%) responden.

23) Membaca Puisi di depan Umum

Sebagian responden kurang (40\%) dalam membaca puisi di depan umum. Sedangkan yang sering membaca karya sastra paling tua ini di depan umum hanya $(22,5 \%)$ responden, yang menjawab cukup sebanyak (30\%) responden. Sisanya tidak pernah membaca puisi di depan umum sebanyak $(37,5 \%)$ responden. 
24) Membaca Prosa di Depan Umum

Gambaran guru sastra yang menarik tidak tergambar pada responden. Karena umumnya responden sebanyak (40\%) kurang dalam membaca prosa atau cerpen di depan umum. Responden yang menjawab sering melakukan kegiatan tersebut sebanyak $(17,5 \%)$ sedangkan sisanya menjawab cukup membaca karangan bebas ini sebanyak (32,5\%) responden, dan responden yang menjawab tidak pernah sebanyak (10\%).

25) Menulis Puisi

Gambaran guru bahasa dan sastra Indonesia profesional itu belum tampak pada bagian ini karena umumnya responden yang sering menulis puisi hanya (32,5\%). Jumlah tersebut masih lebih banyak yang menjawab cukup menulis karangan yang terikat ini sebanyak (35\%) responden. Selebihnya kurang (25\%) sedangkan yang tidak pernah menulis puisi sebanyak $(7,5 \%)$ dari sejumlah responden.

26) Menulis Prosa

Gambaran guru bahasa dan sastra Indonesia yang baik, yang mampu menulis prosa baik novel ataupun cerpen belum tampak dalam penelitian ini. Sebanyak (40\%) responden kurang dalam menulis karangan bebas ini sedangkan yang menjawab sering $(12,5 \%)$ responden. Responden yang menjawab cukup (32,5\%). Sisanya sejumlah (10\%) responden tidak pernah menulis prosa.

27) Menulis Naskah Drama

Dibandingkan karya sastra lain, naskah drama adalah bentuk sastra yang sedikit ditulis. Tidak banyak sastrawan yang menulis naskah drama. Kegiatan itu dianggap lebih kompleks dibandingkan bentuk sastra lainnya. Menulis naskah drama tentunya lebih sulit daripada menulis bentuk lainnya. Oleh karena itu, lebih dari separuh responden (57\%) menjawab kurang dalam menulis drama. Responden yang mengisi sering menulis naskah drama hanya (7,5\%). Responden yang menjawab cukup dalam menulis drama (30\%), selebihnya sebanyak (5\%) responden menjawab tidak pernah menulis.

28) Menulis Esai Sastra

Umumnya responden sebanyak (55\%) kurang dalam menulis esai satra. Responden yang mengisi sering dalam menulis sastra $(2,5 \%)$ responden. Responden yang 
mengisi pilihan cukup dalam menulis esai sastra (20\%). Responden yang menjawab tidak pernah menulis esai sastra $(17,5 \%)$ dari keseluruhan responden.

29) Mengikuti Lomba Sastra

Kegiatan mengikuti lomba terlihat pada jawaban responden yang menjawab sering (10\%). Responden yang menjawab cukup (17,5\%), sedangkan responden yang menjawab kurang (47,5\%). Sisanya (40\%) responden menjawab tidak pernah mengikuti kompetisi sastra ini.

30) Menjadi Juri Lomba Sastra

Responden yang sering menjadi juri dalam lomba sastra $(17,5 \%)$ sedangkan yang menjawab cukup (40\%) responden. Adapun yang menjawab kurang (32,5\%) responden. Sisanya (10\%) menjawab tidak pernah menjadi juri lomba sastra.

31) Mengikuti Perkembangan Sastra

Guru bahasa dan sastra dituntut untuk mengikuti perkembangan sastra Indonesia terbaru atau kontemporer yang ditandai dengan mengenal sastrawan, kritikus serta membaca ulasan-ulasannya, mengikuti diskusi, pelatihan, komunitas dan mengikuti perkembangan sastra.

32) Mengenal Sastrawan Kontemporer

Umumnya responden hanya cukup mengenal (65\%) pengarang-pengarang kontemporer. Sisanya sering mengenal (20\%) dan kurang mengenal (15\%) responden. Gambaran tersebut tentunya tidak akan mewujudkan pembelajaran sastra yang ideal. Siswa tidak memiliki pilihan yang banyak tentang pengarang yang karyanya akan dibaca dan diulas.

33) Mengenal Kritikus Sasta Indonesia Kontemporer

Sebagian besar responden (55\%) cukup kenal beberapa kritikus sastra Indonesia tersebut. Beberapa responden menjawab sering atau sangat mengenal para penjaga dan pelindung sastra $(2,5 \%)$ responden sedangkan sisanya kurang mengenal beberapa kritikus tersebut $(42,5 \%)$ responden.

34) Membaca Ulasan-ulasan Sastra

Lebih dari setengah (60\%) responden menjawab hanya cukup membaca ulasanulasan karya sastra. Responden yang mengisi sering (7,5\%), sedangkan sisanya $(32,5 \%)$ responden kurang membaca ulasan-ulasan sastra. Membaca ulasan-ulasan sastra dianggap penting bagi guru bahasa dan sastra Indonesia karena selain 
memberikan tuntunan memilih karya sastra yang baik untuk dibahas di kelas juga memberi pengetahuan sastra agar pembelajaran sastra di kelas sesuai dengan perkembangan sastra terkini.

35) Mengikuti Diskusi atau Seminar Sastra

Kegiatan mengikuti diskusi atau seminar sastra merupakan kesempatan para guru untuk meningkatkan kompetensi sastranya. Namun, umumnya responden $(52,5 \%)$ kurang dalam mengikuti diskusi atau seminar sastra. Responden yang sering mengikuti diskusi atau seminar sastra sebanyak (2,5\%), dan mengatakan cukup $(37,5 \%)$ responden. Adapun yang menjawab tidak pernah mengikuti diskusi atau seminar sebanyak $(7,5 \%)$ responden.

36) Mengikuti Penghargaan Sastra

Karya-karya terbaik yang dipilih setiap tahun ternyata tidak mendapat perhatian para guru bahasa dan sastra Indonesia. Setengah dari responden (50\%) kurang mengikuti berbagai penghargaan sastra. Responden yang menjawab cukup mengikuti perkembangan perhargaan sastra (15\%). Selebihnya tidak pernah mengikuti penghargaan sastra $(35 \%)$ responden.

37) Mengikuti Pelatihan Sastra

Pelatihan sastra belum diikuti keseluruhan guru bahasa dan sastra Indonesia. Hal ini terlihat lebih dari separuh responden $(62,5 \%)$ merasa kurang mengikuti pelatihanpelatihan sastra. Responden yang sering mengikuti pelatihan sastra sebanyak $(2,5 \%)$. Responden yang menjawab cukup ikut kegiatan yang memberi banyak pengetahuan sastra $(17,5 \%)$, dan sisanya $(17,5 \%)$ tidak pernah mengikuti pelatihan sastra.

38) Mengikuti Komunitas Sastra

Berkenaan dengan hal di atas, responden tidak menggambarkan guru bahasa dan sastra Indonesia yang baik karena sebagian responden (42,5\%) tidak pernah ikut dalam komunitas sastra. Responden yang sering mengikuti (2,5\%). Sisanya yang cukup mengikuti komunitas sebesar (25\%), dan kurang mengikuti (30\%) responden.

39) Melakukan Penelitian Sastra

Gambaran guru bahasa dan sastra Indonesia yang berkualitas tidak terlihat dalam penelitian ini. Sebanyak $(47,5 \%)$ responden kurang melakukan atau diikutkan 


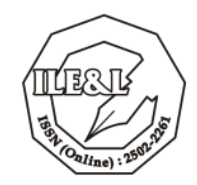

Journal Indonesian Language Education and Literature Vol. 2, No. 2, 2017

http://www.syekhnurjati.ac.id/jurnal/index.php/jeill/

dalam penelitian sastra. Responden yang menjawab cukup dalam melakukan penelitian sastra $(17,5 \%)$, sedangkan sisanya tidak pernah melakukan penelitian $(35 \%)$ responden.

\section{Simpulan}

Berdasarkan paparan tersebut dapat disimpulkan bahwa guru bahasa dan sastra di Wilayah Kotamadya Tangerang Selatan masih jauh dari harapan. Para guru masih memerlukan motivasi yang tinggi untuk sampai menjadi guru dengan kompetensi sastra ideal. Umumnya responden belum menguasai ilmu sastra, melainkan hanya teori tentang unsur sastra. Minat responden belum mengarah pada gambaran kualitas guru yang ideal. Responden sebagian besar memperlihatkan minat yang cukup dalam membaca buku sastra, majalah sastra, menyediakan waktu serta dana khusus untuk bersastra. Para responden tidak sering ke perpustakaan. Kurangnya koleksi buku sastra di sekolah atau di perpustakaan daerah menjadi alasan responden tidak sering mengunjungi perpustakaan.

Pengalaman para guru belum mengarah kepada gambaran kualitas pembelajaran sastra pada masa mendatang. Sebagian besar responden kurang memiliki pengalaman sastra yang dapat ditularkan kepada siswa. Padahal, pengalaman adalah investasi untuk menjadi guru bahasa dan sastra Indonesia ideal. Para guru juga kurang melakukan kegiatan membaca di depan umum dan menulis sastra dalam bentuk prosa, baik fragmen dari novel atau cerpen, drama, dan esai. Beberapa responden cukup sering menulis puisi sedangkan pengalaman mengikuti lomba dan menjadi juri lomba kurang.

Beberapa ahli sastra mendokumentasi karya sastra dengan rinci dalam berbagai buku. Teknologi informasi juga memberikan gambaran pekembangan sastra Indonesia. Namun, hal itu tidak diikuti oleh para responden. Sebagian besar responden hanya cukup mengikuti perkembangan sastrawan, kritikus serta ulasan-ulasan karya sastra. Beberapa metode pengajaran sastra atau cara menyampaikan sastra terbaru kepada siswa tidak diketahui. Sebagian besar responden kurang mengikuti pelatihan atau seminar sastra sedangkan komunitas sastra tidak pernah diikuti. 


\section{Daftar Pustaka}

M.S., Mahsum. 2013. "Teks dalam Pembelajaran Bahasa Indonesia Kurikulum 2013" disampaikan dalam seminar Nasional Bahasa dan Sastra dalam Era Teknologi. Program Pascasarjana, Universitas Mataram, Mataram, 21 April 2013.

Peraturan Menteri Pendidikan Nomor 19 tahun 2005 Tanggal 04 Mei 2007 tentang StandarKualifikasiAkademikdanKompetensi Guru.

Rozak, Abdul. 2012. "Profil Calon Guru bahasa dan sastra Indonesia; Studi pada Mahasiswa Program Studi Pendidikan Bahasa dan Sastra Indonesia."Makalah seminar Nasional Pendidikan Bahasa dan Sastra Indonesia. APBI dan PBSI, FKIP Universitas Pakuan Bogor.27-28 November 2012.

Undang-undang No. 14 tahun 2005 tentang Guru dan Dosen. 